\title{
Distribution of bovine fetuin and albumin in plasma, allantoic and amniotic fluids during development*
}

\author{
P. C. W. Lai, L. L. Huang, D. E. Panrucker, R. B. Church $\dagger$ and \\ F. L. Lorscheider
}

Departments of Medical Physiology, and $\uparrow$ Medical Biochemistry, Faculty of Medicine, University of Calgary, Calgary, Alberta, Canada T2N $1 N 4$

\begin{abstract}
Summary. A radioimmunoassay for bovine fetuin was developed and its specificity and validity established. Albumin was measured by radial-immunodiffusion assay. Fetuin levels in fetal plasma increased from 10 to $15 \mathrm{mg} / \mathrm{ml}$ between 4 and 8 months of gestation; albumin levels remained higher than fetuin. Neonatal plasma fetuin levels rapidly declined during the first 14 days post partum, coincident with a marked reciprocal increase in albumin levels. In allantoic fluid fetuin and albumin concentrations reached a peak at 7 months but fetuin values were always higher. In amniotic fluid both proteins peaked at 8 months; albumin levels were similar to those in allantoic fluid but fetuin values remained consistently lower than those in allantoic fluid throughout gestation. Fetuin levels in maternal plasma declined from 0.7 to 0.4 $\mathrm{mg} / \mathrm{ml}$ between 1 month and term. We conclude that (1) at term there is an abrupt change from fetuin synthesis to increased albumin synthesis by the neonatal liver; (2) fetuin appears to be preferentially accumulated in the allantois whereas albumin is equally concentrated in the allantois and amnion.
\end{abstract}

\section{Introduction}

Serum glycoproteins are considered to be products of amino sugar metabolism in liver (Spiro, 1965) and fetuin is a major glycoprotein in the plasma of fetal calves and lambs which has been isolated and chemically characterized (Spiro, 1960; Marti, Aliau, Bonfils, Vigne \& Moretti, 1973). Studies on fetuin have included the determination of its chemical structure (Nilsson, Norden \& Svensson, 1979; Baenzier \& Fiete, 1979) and investigations into its possible physiological role as an immunoregulator in fetal development (Yachnin, 1975), in fetal thyroid hormone metabolism (Fisher \& Lam, 1974) and as a serum inhibitor of trypsin (Galembeck \& Cann, 1974). These biochemical studies were based on in-vitro experiments with isolated fetuin, and the interpretation of such findings has been limited by inadequate information on changes in the synthesis and subsequent concentration of fetuin in various maternal and fetal fluids during development.

Plasma proteins of mammalian fetuses undergo qualitative and quantitative changes during both fetal and neonatal growth and development. For example, one protein associated with fetal development and studied in detail in several mammalian species including the cow has been alpha $_{1}$-fetoprotein (Branch, 1972; Lai, Forrester, Hay, Hancock \& Lorscheider, 1976; Lai, Mears, Van Petten, Hay \& Lorscheider, 1978b; Ruoslahti \& Seppala, 1979; Smith, Lai, Robertson, Church \& Lorscheider, 1979). Since the bovine fetus also synthesizes fetuin, the

* Reprint requests to: Dr F. L. Lorscheider, Department of Medical Physiology, Faculty of Medicine, University of Calgary, Calgary, Alberta, Canada T2N 1 N4. 
objectives of this study were to develop a radioimmunoassay system for bovine fetuin, to determine the changes in the level of fetuin (mol. wt 48 400) (Spiro, 1960) in fetal and neonatal plasma, maternal plasma, amniotic and allantoic fluids during development, and to compare the physiological distribution of fetuin with that of albumin (mol. wt 65 500) (King \& Spencer, 1970).

\section{Materials and Methods}

\section{Antiserum production}

Fetuin (99\% pure, Spiro method) was obtained from Gibco Co. (Calgary, Alberta, Canada). Antiserum to fetuin was produced in a rabbit by s.c. injections $(2 \mathrm{mg})$ of $0.2 \%$ fetuin solution emulsified in 50\% Freund's complete adjuvant on Days 0,6 and 33. Blood was collected on Day 43 and the serum separated. Antiserum $(3 \mathrm{ml})$ was absorbed on a $0.9 \times 9 \mathrm{~cm}$ Sepharose 4B column which had $1 \mathrm{ml}$ non-pregnant cow serum covalently linked to it as previously described (Lai, Hay \& Lorscheider, 1978a). The monospecificity of the absorbed rabbit anti-bovine fetuin was confirmed by immunoelectrophoresis (Scheidegger, 1955).

\section{Radioisotope labelling}

Pure fetuin was labelled with carrier-free ${ }^{125}$ ( (Amersham, Arlington Heights, Illinois, U.S.A.) and subsequently purified by gel filtration carried out by the method of Greenwood, Hunter \& Glover (1963) as modified by Lai et al. (1978a).

\section{Standardization}

Pure fetuin standards used in the radioimmunoassay were prepared by weighing freeze-dried fetuin which was de-salted by dialysis against distilled water. The salt-free fetuin standard was dissolved in radioimmunoassay buffer $(50 \mathrm{~mm}$-sodium phosphate, $0.15 \mathrm{M}-\mathrm{NaCl}, 3 \%(\mathrm{v} / \mathrm{v})$ normal rabbit serum, $0 \cdot 02 \% \mathrm{NaN}_{3}$ ), $\mathrm{pH} 7 \cdot 4$.

\section{Radioimmunoassay}

The ${ }^{125}$ I-labelled fetuin was diluted in assay buffer such that the radioactivity was 120000 d.p.m./ml. Each radioimmunoassay tube $(10 \times 75 \mathrm{~mm})$ contained the following components: $0 \cdot 1$ $\mathrm{ml}$ assay buffer, $0.1 \mathrm{ml}$ fetuin standard or unknown sample, $0.1 \mathrm{ml}{ }^{125}$ I-labelled fetuin, $0.2 \mathrm{ml}$ antiserum to bovine fetuin (diluted $1: 2300$ in assay buffer). The tubes were incubated at $4{ }^{\circ} \mathrm{C}$ for

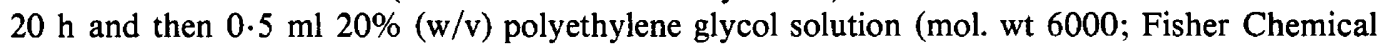
Co., Calgary, Alberta; in $50 \mathrm{~mm}$-sodium phosphate, $0.15 \mathrm{M}-\mathrm{NaCl}, \mathrm{pH} 7.4$ ) was added. The contents of each assay tube were stirred on a vortex mixer for $10 \mathrm{sec}$ and centrifuged $(4000 \mathrm{~g}$, at $4^{\circ} \mathrm{C}$ ) for $30 \mathrm{~min}$; the supernatant was removed by aspiration. The radioactivity bound minus non-specific binding in the precipitate (B) was divided by the radioactivity bound minus non-specific binding in assay tubes that contained no unlabelled fetuin $\left(\mathrm{B}_{0}\right)$ and the ratio was expressed as a percentage. Non-specific binding was determined by omitting the fetuin antiserum in 3 assay tubes.

\section{Radial-immunodiffusion assay}

Quantitation of fetuin and albumin was also performed by radial-immunodiffusion assay (Mancini, Carbonara \& Heremans, 1965) using 2.5\% (v/v) antiserum to bovine fetuin and $1 \%$ 
(v/v) rabbit antiserum to bovine albumin (Miles Biochemicals, Elkhart, Indiana, U.S.A.) in 1\% $(w / v)$ agarose gels.

\section{Animals}

The 61 blood samples were obtained by venepuncture from 10 pregnant or post-partum cows with known breeding dates at a local ranch. Plasma specimens were also obtained from 7 non-pregnant cows. Samples of amniotic fluid $(n=92)$, allantoic fluid $(n=61)$ and fetal plasma $(n=19)$ were obtained following removal of the intact conceptus from the uterus of cows at a local slaughterhouse or at the Animal Reproduction Laboratory, Colorado State University, Fort Collins, Colorado, U.S.A. Forty-six of the allantoic and amniotic fluid samples obtained from different animals were matched for gestational age. The fetal age was estimated from crown-rump length and fetal weight (Salisbury \& VanDemark, 1961; Arthur, 1975) or from known mating dates (cows at Colorado State University).

Jugular vein blood samples $(n=15)$ were also obtained from 3 calves at intervals for 3 months after birth.

\section{Antiserum characterization}

\section{Results}

Initially, it was found that the antiserum produced against commercially available fetuin was not monospecific because it also precipitated a protein in fetal calf serum which had an electrophoretic mobility slightly faster than that of fetuin by immunoelectrophoresis. This antiserum was made monospecific by chromatography on a Sepharose column to which serum from a non-pregnant cow was covalently linked. The resultant rabbit antiserum to bovine fetuin was demonstrated to be monospecific for fetuin by immunoelectrophoresis (Text-fig. 1a).

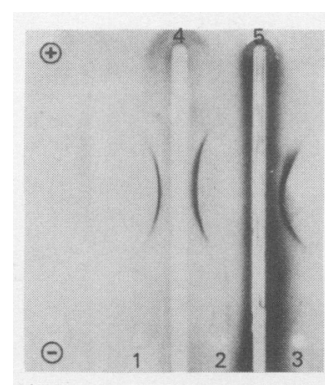

(a)

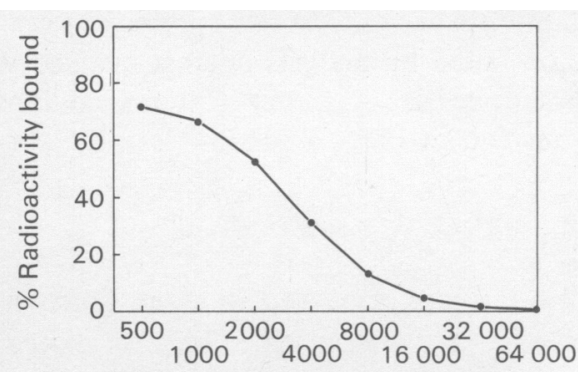

(b)

Rabbit anti-bovine fetuin titre

Text-fig. 1. Preparation of an antiserum to bovine fetuin. (a) An immunoelectrophoresis gel plate with fetal calf serum in Well 1 , pure fetuin $(1 \mathrm{mg} / \mathrm{ml})$ in Well 2, purified alpha, -fetoprotein (Lai, Peters \& Lorscheider, 1978c) in Well 3, the rabbit antiserum to bovine fetuin in Trough 4 and rabbit antiserum to bovine alpha ${ }_{1}$-fetoprotein (Lai et al., 1978c) in Trough 5. (b) The antiserum dilution titre curve. Each point represents the mean of triplicate determinations.

The antiserum dilution titre curve was prepared (Text-fig. 1b) and the titre of the antiserum, defined as the reciprocal of that dilution of antibody that bound $50 \%$ of the ${ }^{125}$ I-labelled fetuin, was $1: 2300$.

\section{Radioisotope labelling}

Fetuin labelled with ${ }^{125}$ I was chromatographed on a Sephadex G50 (Pharmacia, Uppsala, Sweden) column and revealed two distinct radioactive peaks. The first peak corresponded to 
${ }^{125}$ I-labelled fetuin and was estimated to have a specific activity of $0.08 \mathrm{mCi} / \mu \mathrm{g}$ protein. The purified ${ }^{125}$ I-labelled fetuin was stabilized by adding an equal volume of assay buffer and stored at $4^{\circ} \mathrm{C}$ for up to 1 week. On the basis of its specific activity, it was calculated that approximately $68 \mathrm{pg}{ }^{125} \mathrm{I}$-labelled fetuin was added to each radioimmunoassay tube.

\section{Radioimmunoassay}

The radioimmunoassay standard curve is illustrated in Text-fig. 2(a). The sensitivity of the radioimmunoassay, defined at twice the standard deviation of the determination of zero, was $\mathbf{4 0}$ $\mathrm{ng} / \mathrm{ml}$. The working range of the assay was $50-750 \mathrm{ng} / \mathrm{ml}$ and specimens containing fetuin at concentrations of $>750 \mathrm{ng} / \mathrm{ml}$ were diluted in the assay buffer before assay. The non-specific binding was $2 \cdot 5 \%$.
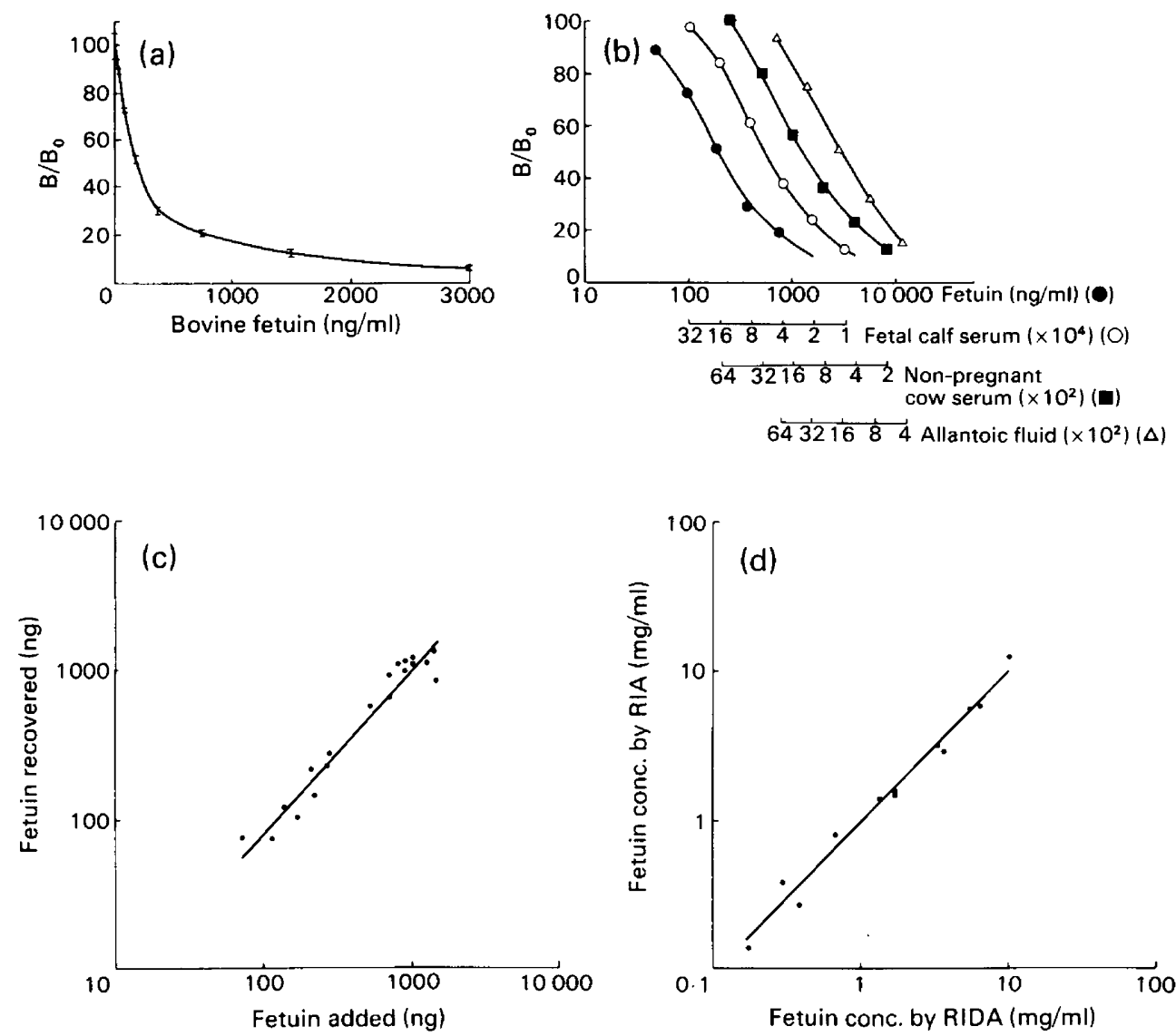

Text-fig. 2. Characteristics of the fetuin assay. (a) Radioimmunoassay standard curve for fetuin. Each point represents the mean and range of triplicate determinations. (b) Comparison of dose-response dilution curves of various physiological fluids containing fetuin with the pure fetuin standard. Each point represents the mean of triplicate determinations. (c) Analytical recovery of fetuin in the radioimmunoassay. Known quantities of pure fetuin were added to 19 previously assayed samples. The graph illustrates the correlation of measured fetuin levels recovered in the samples and the theoretical calculated value based on fetuin added (regression line: $y=-0.296+1.10 x ; r=0.974)$. (d) Correlation of fetuin concentrations in 12 plasma samples measured by radial-immunodiffusion assay (RIDA) with those measured by radioimmunoassay (RIA) (regression line: $y=-0.0905+1.025 x ; r=0.990$ ). 
The specificity of the assay was established by using a highly purified commercial fetuin preparation for the radioisotope labelling and the monospecific antiserum. Assay specificity was also evaluated by comparison of the dose-response curves of various physiological fluids containing fetuin with that of pure fetuin in the radioimmunoassay system. The slopes of such curves were very similar (Text-fig. 2b), suggesting that the assay is specific for fetuin.

The validity of the assay was confirmed by an analytical recovery study. Various amounts of pure fetuin (73-1460 ng) were added to 19 previously assayed samples which were subsequently analysed by the radioimmunoassay. The mean analytical recovery for these samples was $99.0 \%$ (s.e.m. 3.4\%) (Text-fig. 2c). Fetuin values of plasma samples assayed by radioimmunoassay and by radial-immunodiffusion assay were also compared and the values obtained were highly correlated (Text-fig. 2d).

\section{Fetuin levels during development}

As shown in Text-fig. 3(a) fetuin levels in fetal plasma increased from $10 \mathrm{mg} / \mathrm{ml}$ at 4 months to $15 \mathrm{mg} / \mathrm{ml}$ at 8 months of gestation. At the time of parturition plasma fetuin levels declined, but were still 3 times the normal adult level by 3 months after birth. Albumin levels were always greater than those of fetuin and they increased rapidly as fetuin concentrations decreased after birth.

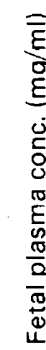

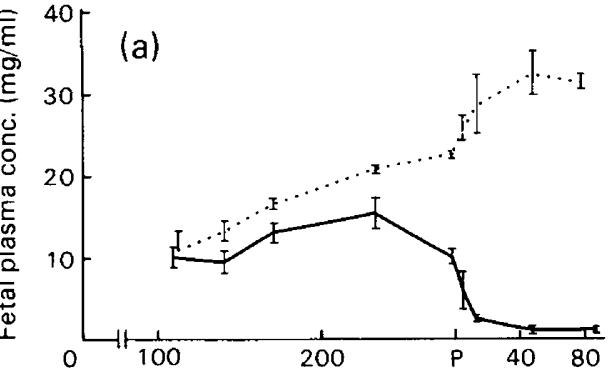

है

(d)

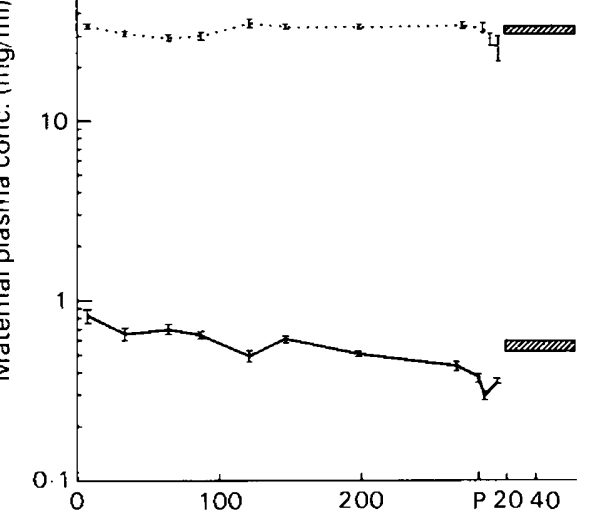

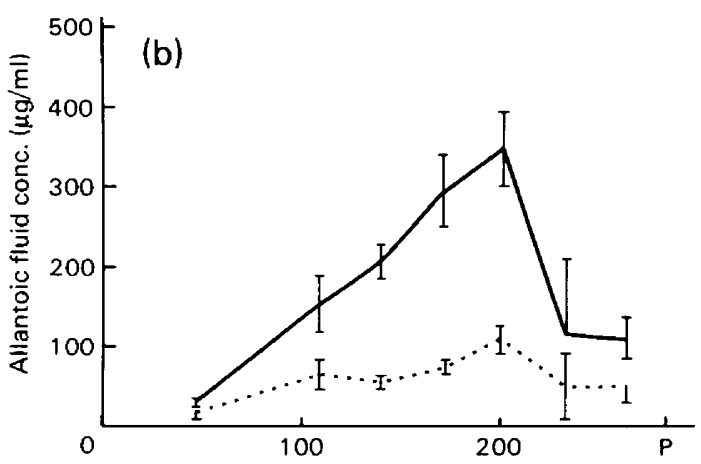

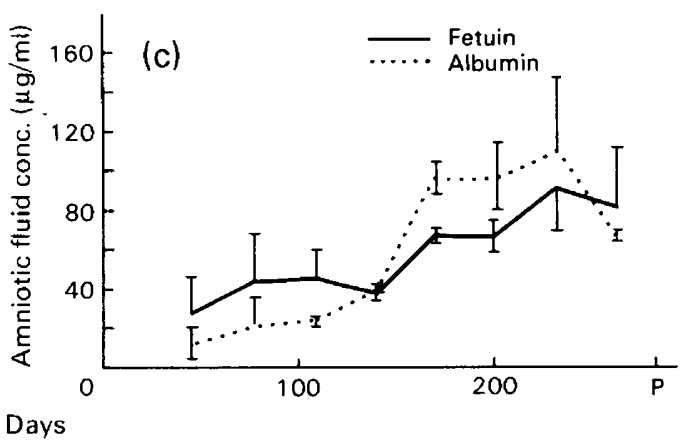

Text-fig. 3. Concentrations of fetuin and albumin in (a) fetal and neonatal calf plasma, (b) allantoic fluid, (c) amniotic fluid, and (d) maternal plasma during and after gestation. Values are mean \pm s.e.m. for (a) 3-5, (b) 3-17, (c) 3-23 and (d) 3-10 animals. In (d) the hatched areas represent the range for 7 non-pregnant cows. $P=$ parturition. 
In the allantoic fluid fetuin is present in higher concentrations than albumin throughout gestation (Text-fig. 3b) and is the most dominant protein during the middle third of gestation as revealed by disc polyacrylamide gel electrophoresis (unpublished observation).

Amniotic fluid concentrations of fetuin and albumin throughout gestation appeared to be similar and gradually increased, with the highest concentrations being observed at 8 months (Text-fig. 3c). Although albumin levels in amniotic and allantoic fluid were similar, fetuin levels were consistently lower in the amniotic fluid throughout gestation.

In maternal plasma concentrations of fetuin decreased from $0.7 \mathrm{mg} / \mathrm{ml}$ at 1 month of gestation to about $0.4 \mathrm{mg} / \mathrm{ml}$ at term and for at least 3 weeks post partum (Text-fig. $3 \mathrm{~d}$ ). Levels of albumin appeared to be relatively stable during pregnancy although there was a decrease to $<30 \mathrm{mg} / \mathrm{ml}$ at 2 months of pregnancy.

\section{Discussion}

This radioimmunoassay permitted the accurate determination of changes in the concentration of fetuin in various fluids during fetal and neonatal development. The radioimmunoassay technique has an advantage over other immunological techniques such as Ouchterlony double diffusion or radial-immunodiffusion assays because fetuin is present in amniotic fluid during early gestation in concentrations lower than the limit of detection of these latter methods. Normal rabbit serum was used in the buffer system of our radioimmunoassay procedure instead of bovine serum albumin because the source from which commercially available albumin is purified is unknown and fetuin contamination is possible if calf sera are used as the source of albumin. A double-antibody assay system to precipitate the ${ }^{125}$ I-labelled fetuin-antibody complex was avoided because such a procedure involves the use of a secondary antibody produced in a goat or sheep, and it has been reported that sera of these animals contain proteins that cross-react with bovine fetuin (Bergmann, Levine \& Spiro, 1962).

Fetuin levels in fetal plasma from 4-9 months gestation are similar to those reported for cows by Bergmann et al. (1962). However, we found that plasma fetuin levels decline at or near term in bovine fetuses. Furthermore, at term and during the first 2 weeks after birth the rapid decline in fetuin concentration in calf plasma and a concomitant rapid increase in plasma albumin concentration suggest that there is a change at this time from fetuin to increased albumin synthesis by the fetal-neonatal liver. It would be of interest to investigate the molecular mechanisms and physiological significance of the decrease in fetuin synthesis, a protein rich in carbohydrates (Spiro, 1960; Marti et al., 1973), and a corresponding increase in the synthesis of albumin, a non-glycoprotein (Brown, 1976).

Following the rapid decline in fetuin levels in calf plasma during the first 2 weeks of post-natal life the fall in concentration is slower in subsequent months. By 3 months post partum

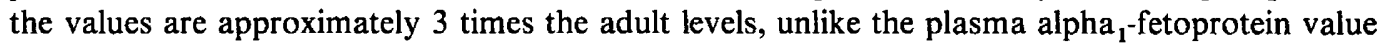
which has declined to adult levels by this time (Lai, Smith, Church \& Lorscheider, 1979). The present findings on fetuin synthesis in both fetal and post-natal calves are different from our earlier reports on alpha ${ }_{1}$-fetoprotein (Lai et al., 1979; Smith et al., 1979) which suggests that either the quantitative proportion of hepatocytes that are probably responsible for synthesizing fetuin and alpha ${ }_{1}$-fetoprotein varies as a function of development, or that hepatocytes retain fetuin synthetic capability for a longer period than they do that for alpha $a_{1}$-fetoprotein. Further studies should determine whether there are 2 populations of hepatocytes secreting fetuin and alpha $a_{1}$-fetoprotein or if both proteins are secreted by the same cell.

Fetuin appears to be an ubiquitous protein whose distribution space is not limited within the fetal intravascular space since it is also found in allantoic or amniotic fluid. The source of fetuin in these extra-fetal fluids is likely to be fetal rather than maternal because the concentration of fetuin is much higher in fetal than in maternal plasma and because fetal plasma proteins of 
comparable molecular weight can be readily excreted by the kidney of human fetuses (Weiss, Macri \& Elligers, 1976). It is believed that bovine fetal urine ultimately contributes to the formation of both allantoic and amniotic fluids (Arthur, 1969). In the present study, we observed that the concentration of fetuin in allantoic fluid was 1-5 times higher than that in amniotic fluid throughout gestation. Others have reported that for most of bovine fetal development the allantoic fluid volume is larger than that of amniotic fluid (Arthur, 1969; Eley et al., 1978). Since the concentration of fetuin in these fluids does not accurately reflect the total amount of this protein present in each fluid compartment, we have calculated the total amount of fetuin present in the allantoic and amniotic sacs by multiplying the concentration of fetuin for each sample with known gestational fluid volume data established by others (Arthur, 1969; Eley et al., 1978). From such calculations we estimate that the total quantity of fetuin is 2-12 times higher in the allantois than in the amnion throughout gestation. Similar calculations for albumin revealed a total quantity only 1-2 times higher in the allantois than in the amnion. It would therefore appear that there is a preferential accumulation of fetuin in the allantoic sac throughout gestation. One possible explanation for this relationship may be that fetuin is first excreted into allantoic fluid and then transferred to amniotic fluid. Studies with radioisotope-labelled fetuin are needed to confirm this interpretation. Fetuin synthesis appeared to begin very early during the development of the embryo and could be detected in both amniotic and allantoic fluids as early as 3 weeks (unpublished observation).

This study was supported by a grant from the Alberta Children's Hospital Research Foundation. P.C.W.L. is a recipient of a Medical Research Council Summer Undergraduate Scholarship. The contribution of the Animal Reproduction Laboratory, Colorado State University, Fort Collins, Colorado and Canada Packers, Ltd, Calgary, Alberta, is gratefully acknowledged, as is the access to animals at Alberta Livestock Transplants, Calgary, Alberta.

\section{References}

Arthur, G.H. (1969) The fetal fluids of domestic animals. J. Reprod. Fert., Suppl. 9, 45-52.

Arthur, G.H. (1975) Veterinary Reproduction and Obstetrics, 4th Edn, p. 47. Baillière Tindall, London.

Baenziger, J.U. \& Fiete, D. (1979) Structure of the complex oligosaccharides of fetuin. J. biol. Chem. 254, 789-795.

Bergmann, F.H., Levine, L. \& Spiro, R.G. (1962) Fetuin: immunochemistry and quantitative estimation in serum. Biochim. Biophys. Acta 58, 41-51.

Branch, W.R. (1972) The ontogeny of alpha-fetoprotein in the foetal and neonatal rabbit, and its experimental induction in adult rabbits. Int. $J$. Cancer 10 , $451-457$.

Brown, J.R. (1976) Structural origins of mammalian albumin. Fedn Proc. Fedn Am. Socs exp. Biol. 35, 2141-2144.

Eley, R.M., Thatcher, W.W., Bazer, F.W., Wilcox, C.J., Becker, R.B., Head, H.H. \& Adkinson, R.W. (1978) Development of the conceptus in the bovine. J. Dairy Sci. 61, 467-473.

Fisher, D.A. \& Lam, R.W. (1974) Thyroid hormone binding by bovine and ovine fetuin. Endocrinology 94, 49-54.

Galembeck, F. \& Cann, J.R. (1974) Fetuin as a trypsin inhibitor. Arch. Biochem. Biophys. 164, 326-331.
Greenwood, F.C., Hunter, W.M. \& Glover, J.S. (1963) The preparation of ${ }^{131}$ I-labelled human growth hormone of high specific activity. Biochem. J. 89, 114-123.

King, T.P. \& Spencer, M. (1970) Structural studies and organic ligand-binding properties of bovine plasma albumin. J. biol. Chem. 245, 6134-6148.

Lai, P.C.W., Forrester, P.I., Hay, D.M., Hancock, R.L. \& Lorscheider, F.L. (1976) Rat alpha-fetoprotein: isolation, radioimmunoassay and fetal-maternal distribution during pregnancy. $J$. Reprod. Fert. 48, 1-8.

Lai, P.C.W., Hay, D.M. \& Lorscheider, F.L. (1978a) Radioimmunoassay of ovine alpha-fetoprotein. $J$. Immunol. Methods 20, 1-10.

Lai, P.C.W., Mears, G.J., Van Petten, G.R., Hay, D.M. \& Lorscheider, F.L. (1978b) Fetal-maternal distribution of ovine alpha-fetoprotein. Am. J. Physiol. 235, E27-E31.

Lai, P.C.W., Peters, E.H. \& Lorscheider, F.L. (1978c) Bovine fetus-specific serum proteins: purification and characterization of $\alpha_{1}$-fetoprotein and immunological identification of $\alpha_{2}$ and $\beta$-fetoproteins. Biochim. Biophys. Acta 535, 138-149.

Lai, P.C.W., Smith, K.M., Church, R.B. \& Lorscheider, F.L. (1979) Radioimmunoassay of bovine alphaDownloaded from Bioscientifica.com at 04/26/2023 10:14:54AM via free access 
fetoprotein in maternal plasma during pregnancy and in newborn calf plasma. In Carcinoembryonic Proteins, Vol. II, pp. 309-315. Ed. F.-G. Lehmann. Elsevier/North Holland Biomedical Press, Amsterdam.

Mancini, G., Carbonara, A.O. \& Heremans, J.F. (1965) Immunochemical quantitation of antigens by single radialimmunodiffusion. Immunochemistry $2,235-$ 254.

Marti, J., Aliau, S., Bonfils, C., Vigne, C. \& Moretti, J. (1973) Preparation, constantes, physiques et constitution chimique de la fetuine d'agneau. Biochim. Biophys. Acta 303, 349-359.

Nilsson, B., Norden, N.E. \& Svensson, S. (1979) Structural studies on the carbohydrate portion of fetuin. J. biol. Chem. 254, 4545-4553.

Ruoslahti, E. \& Seppala, M. (1979) $\alpha$-Fetoprotein in cancer and fetal development. Adv. Cancer Res. 29, 275-346.

Salisbury, G.W. \& VanDemark, N.L. (1961) Physiology of Reproduction and Artificial Insemination of Cattle, pp. 122-124. W. H. Freeman \& Co., San Francisco.

Scheidegger, J.J. (1955) Une micro-méthode de l'immuno-électrophorésis. Int. Arch. Allergy Appl. Immunol. 7, 103-110.

Smith, K.M., Lai, P.C.W., Robertson, H.A., Church, R.B. \& Lorscheider, F.L. (1979) Distribution of alpha ${ }_{1}$-fetoprotein in fetal plasma, allantoic fluid, amniotic fluid and maternal plasma of cows. $J$. Reprod. Fert. 57, 235-238.

Spiro, R.G. (1960) Studies on fetuin, a glycoprotein of fetal serum. 1. Isolation, chemical composition, and physiochemical properties. J. biol. Chem. 235, 2860-2869.

Spiro, R.G. (1965) Amino sugars and macromolecules containing amino sugars in liver. In The Amino Sugars, Vol. II A, pp. 47-78. Eds E. A. Balazs \& R. W. Jeanloz. Academic Press, New York.

Weiss, R.R., Macri, J.N. \& Elligers, K.W. (1976) Origin of amniotic fluid alpha-fetoprotein in normal and defective pregnancies. Obstet. Gynec. 47, 697-700.

Yachnin, S. (1975) Fetuin, an inhibitor of lymphocyte transformation: the interaction of fetuin with phytomitogens and a possible role for fetuin in fetal development. J. exp. Med. 141, 242-256.

Received 11 September 1980 